\title{
UNCERTAINTY OF MEASUREMENT RESULTS IN FUEL ANALYSES
}

\section{Paulo Roberto Guimarães Couto - INMETRO/DIMCI}

Address: Avenida Nossa Senhora das Graças, 50

Vila Operária, Xerém, CEP 25.250-020 - Duque de Caxias - RJ prcouto@inmetro.gov.br

\section{Ilse Maria Guilhermino Lemos} UFRJ/ ESCOLA DE QUÍMICA

Address: Centro de Tecnologia, Bloco E SIQUIM

Cidade Universitária, Ilha do Fundão, CEP 21.945-000 - Rio de Janeiro - RJ imguilhermino@inmetro.gov.br

\section{ABSTRACT}

The result of a measurement serves as a parameter in a variety of applications, such as: the sale of products; the inspection of materials in relation to specifications/ limits set by a standard; providing support for a judicial ruling; improving the specific quality of products; estimating profitability and making comparisons with a view to mutual recognition between metrology laboratories and systems. The aim of this work is to demonstrate the relevance and applications of the ISO GUM 95 in the fuel analyses conducted by the LABCOM at the EQ/UFRJ, presenting results tables and discussions. The paper further discusses the strategic importance of metrological reliability of measurement results and of the actions of a laboratory within the context of the science of metrology in Brazil.

Key words: calculation of uncertainty; measurement results; metrological reliability.

\section{INTRODUCTION}

With the globalization process and consequent opening of the Brazilian economy to the external market, it is vitally important that industries, laboratories, research centers etc. in the country lose no time in demonstrating the same level of quality as that declared for their products and services, thereby taking a secure foothold in the context of national and international competition.

In the ISO 9000 family of standards, three important stages may be cited: the acquisition of raw materials, process control and the final quality of products. If these stages are to be firmly established, the interdependence between metrology, standardization and quality must be obeyed.

Despite such strict interdependence between metrology, standardization and quality, there are still three types of users of metrology services that have been identified in the country:

I) those who have a complete understanding of the integration between metrology, tandardization and quality;

II) those who use metrology services only to comply with legal and administrative requirements;
III) those who still ignore the importance of metrology as a tool for quality.

Additionally, many people still confuse the terms traceability and metrological reliability, interpreting incorrectly the aims of the NBR ISO/IEC 17025 and ISO 9000 standards.

The losses that occur because of errors, production defects, time lost in repeating work, excess waste and other types of wastage have risen to very high levels as a proportion of the Gross Domestic Product (GDP). Without doubt, metrology is central to much of this waste, for reasons such as i) the large number of instruments existing in Brazilian industries that are too precise for the specific needs of a process, and ii) measurement errors in the sale of products.

As regards specifying an instrument without previously analyzing the tolerance of the specific process, this can lead to a very high price in terms of cost/benefit. In other words, the tolerance of a process does not generally justify the acquisition of certain instruments. In consequence of this fact, it is very common to find within Brazilian industry sets of highly precise instruments being underutilized and scrapped, thereby contributing towards the overall waste and cost incurred in manufacturing the final product.

Additionally, specifying an instrument with too rough a 
degree of precision for the tolerances of a given process may also lead to results involving great waste. For example, a $2 \%$ error in measuring the filling of 50-liter cylinders with nitrogen leads to a waste of around $49 \%$ of a day's production of 1000 cylinders over a period of 20 days. If we apply this evaluation model to other areas, like the sale of electricity, natural gas, petroleum and steel etc., it is once again clear that poor metrology practices are a key cause of wastage.

All the analyses made in the previous paragraphs are based on the results of measurements. The expression of a measurement result consists of its most probable value corrected by the systematic error plus or minus the uncertainty of the measurement. There have been increasing demands made on laboratories for them to show evidence of the quality of their results. Indeed, with increasing globalization, particularly involving overseas trade, it is becoming more necessary that the reliability of measurement results be proven. For this reason, laboratories are often asked to participate in laboratory comparisons (proficiency programs) with the aim of mutual recognition and the consequent elimination of duplicated efforts to obtain a measurement result. Proof of the reliability of these results from outside the organization itself is vital if this objective is to be reached.

\section{AIM}

This work was developed in the Laboratório de Combustíveis e Derivados de Petróleo - LABCOM, of the Departamento de Processos Orgânicos at the Escola de Química/Universidade Federal do Rio de Janeiro, in conjunction with the INSTITUTO NACIONAL DE METROLOGY, NORMALIZAÇÃO E QUALIDADE INDUSTRIAL - INMETRO, with which it has a technical and scientific cooperation agreement. $\angle A B C O M$ is equipped to undertake research work on the quality of fuels and lubricants, as well as the control and monitoring of the quality of liquid derivatives of petroleum.

The role of INMETRO is to put into practice the scientific and industrial metrology policies, legal metrology, standardization and quality accreditation of the country's industrial products, in compliance with the standards passed by CONMETRO.

\section{METHODOLOGY}

To develop this work, the fundamentals of the International Organization for Standardization, Guide to the Expression of Uncertainty in Measurement, Geneva, 1993, revised and reprinted in 1995” - ISO GUM 95, were applied. This document provides an organized form for estimates of uncertainty in measurements to be made, without which results could not be compared. The ISO GUM 95 is also established as a highly powerful tool in defining all the instrumentation in a given process.

For chemical laboratories there exists specific literature, the EURACHEM/CITAC Guide to Quantifying Uncertainty in Analytical Measurement - Second Edition - Final Draft: April 2000. However, as was mentioned earlier, the ISO GUM 95 is the basis for any document dealing with the issue of uncertainty in measurements, so nothing restricts one from applying the ISO GUM 95 to estimate the uncertainty of measurement results in tests conducted in a chemical laboratory. In this work, we will present its application in tests for the Level of Anhydrous Ethyl Alcohol in Automotive Gasoline - NBR 13992, Level of Hydrocarbons Present in Anhydrous Ethyl Alcohol Fuel - NBR 13993 and the Relative Density of Petroleum Products ASTM $D$ 1298. These are specifications determined in the ANP Regulations \# 197 of December 28, 1999, \# 45 of March 16, 2001 and \# 032 of August 4, 1997, used in the inspection and quality control of automobile fuels.

In this work, we will present the application of the ISO GUM 95 for estimating uncertainty in the following tests: i) the level of anhydrous alcohol present in automotive gasoline; ii) level of gasoline present in hydrous ethyl alcohol fuel; and iii) the relative density in petroleum products.

According to the recommendations of the REQUISITOS GERAIS PARA COMPETÊNCIA DE LABORATÓRIOS DE ENSAIO E CALIBRAÇÃO - NBR ISO/IEC 17025:JAN 2001 standard, all measurements in the tests were made with calibrated instruments, and corrected from their standard deviations, as expressed in their respective certificates. 


\section{RESULTS/DISCUSSION}

Below are presented the uncertainty results tables for the tests, according to the recommendations contained in the ISO GUM 95.

\section{LEVEL OF ANHYDROUS ETHYL ALCOHOL PRESENT IN AUTOMOTIVE GASOLINE NBR 13992}

- The level of alcohol present in the gasoline may be defined by the expression:

$$
C \%=\frac{\left(V_{(\text {água }+ \text { álcool })}\right)-\left(V_{i(\text { água })}\right)}{V_{i(\text { gasolina })}} * 100, \text { where }
$$

$C \%=$ percentage alcohol content;

$V_{(\text {água }+ \text { álcool })}=$ final volume of alcohol + water;

$V_{i(a)}=$ initial water volume;

$V_{\text {i(gasolina) }}^{\text {i(água) }}=$ initial gasoline volume.

\begin{tabular}{|c|c|c|c|c|c|c|}
\hline Sources of Uncertainty & Value(mL) & Distribution & Divisor & $\begin{array}{c}\text { Sensitivity } \\
\text { coefficient } / \mathrm{mL} \text {. }\end{array}$ & $\begin{array}{l}\text { Uncertainty } \\
(\mathrm{mL} / \mathrm{mL})\end{array}$ & $\begin{array}{l}\text { Degrees } \\
\text { of } \\
\text { freedom }\end{array}$ \\
\hline $\begin{array}{l}\text { Calibration certificate for the } \\
\text { measuring cylinder }(100 \mathrm{~mL})\end{array}$ & 0.2 & normal & 2.25 & 0.02 & $1.78 \times 10^{-03}$ & $\infty$ \\
\hline $\begin{array}{l}\text { Calibration certificate for the } \\
\text { thermometer }(50 \mathrm{~mL}) *\end{array}$ & $1.26 \times 10^{-03}$ & normal & 2 & 0.02 & $1.26 \times 10^{-05}$ & $\infty$ \\
\hline $\begin{array}{c}\text { Volume expansion coefficient of } \\
\text { the water }(50 \mathrm{~mL})\end{array}$ & $2.8 \times 10^{-03}$ & $\begin{array}{l}\text { rectang } \\
\text { ular }\end{array}$ & $\sqrt{3}$ & 0.02 & $3.23 \times 10^{-05}$ & $\infty$ \\
\hline $\begin{array}{l}\text { Calibration certificate for the } \\
\text { measuring cylinder }(50 \mathrm{~mL})\end{array}$ & 0.2 & normal & 2.25 & 0.004 & $3.56 \times 10^{-04}$ & $\infty$ \\
\hline $\begin{array}{l}\text { Calibration certificate for the } \\
\text { thermometer }(50 \mathrm{~mL}) *\end{array}$ & $1.26 \times 10^{-03}$ & normal & 2 & 0.004 & $2.52 \times 10^{-06}$ & $\infty$ \\
\hline $\begin{array}{l}\text { Volume expansion coefficient of } \\
\text { the gasoline }(50 \mathrm{~mL})\end{array}$ & $2.8 \times 10^{-03}$ & $\begin{array}{l}\text { rectang } \\
\text { ular }\end{array}$ & $\sqrt{3}$ & 0.004 & $6.47 \times 10^{-06}$ & $\infty$ \\
\hline $\begin{array}{l}\text { Calibration certificate for the } \\
\text { measuring cylinder }(60 \mathrm{~mL})\end{array}$ & 0.2 & normal & 2.25 & 0.02 & $1.78 \times 10^{-03}$ & $\infty$ \\
\hline $\begin{array}{l}\text { Calibration certificate for the } \\
\text { thermometer }(60 \mathrm{~mL}) *\end{array}$ & $1.61 \times 10^{-02}$ & normal & 2 & 0.02 & $1.61 \times 10^{-04}$ & $\infty$ \\
\hline $\begin{array}{l}\text { Volume expansion coefficient of } \\
\text { the water }+ \text { alcohol }(60 \mathrm{~mL})\end{array}$ & $3.36 \times 10^{-03}$ & $\begin{array}{l}\text { rectang } \\
\text { ular }\end{array}$ & $\sqrt{3}$ & 0.02 & $3.88 \times 10^{-05}$ & $\infty$ \\
\hline Combined Uncertainty & & normal & & & $2.55 \times 10^{-03}$ & $\infty$ \\
\hline $\begin{array}{l}\text { Expanded Uncertainty } \\
(95 \%: k=2)\end{array}$ & & normal & & & $\begin{array}{c}5.1 \times 10^{-03} \\
(0.51 \%)\end{array}$ & $\infty$ \\
\hline
\end{tabular}

Table 1 - Level of anhydrous alcohol present in automobile gasoline. 


\section{LEVEL OF HYDROCARBONS PRESENT IN \\ ANHYDROUS ETHYL ALCOHOL FUEL \\ NBR 13993}

The hydrocarbon content may be defined by the expression:

$$
C \%=\frac{\left(V_{\text {(total })}\right)-\left(V_{(\text {fase aquosa })}\right)}{V_{i(\text { álcool })}} * 100, \text { where }
$$

\begin{tabular}{|c|c|c|c|c|c|c|}
\hline Sources of uncertainty & Value $(\mathrm{mL})$ & Distribution & Divisor & $\begin{array}{c}\text { Sensitivity } \\
\text { coefficient } / \mathrm{mL} .\end{array}$ & $\begin{array}{c}\text { Uncertaint } \\
y \\
(\mathrm{~mL} / \mathrm{mL})\end{array}$ & $\begin{array}{l}\text { Degrees } \\
\text { of } \\
\text { freedom }\end{array}$ \\
\hline $\begin{array}{l}\text { Calibration certificate for the } \\
\text { measuring cylinder }(100 \mathrm{~mL})\end{array}$ & 0.2 & normal & 2.25 & 0.02 & $1.78 \times 10^{-03}$ & $\infty$ \\
\hline $\begin{array}{l}\text { Calibration certificate for the } \\
\text { thermometer }(50 \mathrm{~mL}) *\end{array}$ & $1.26 \times 10^{-03}$ & normal & 2 & 0.02 & $1.26 \times 10^{-05}$ & $\infty$ \\
\hline $\begin{array}{l}\text { Volume expansion coefficient } \\
\text { of the water }(50 \mathrm{~mL})\end{array}$ & $2.8 \times 10^{-03}$ & $\begin{array}{l}\text { rectang } \\
\text { ular }\end{array}$ & $\sqrt{3}$ & 0.02 & $3.23 \times 10^{-05}$ & $\infty$ \\
\hline $\begin{array}{l}\text { Calibration certificate for the } \\
\text { easuring cylinder }(50 \mathrm{~mL})\end{array}$ & 0.2 & normal & 2.25 & 0.004 & $3.56 \times 10^{-04}$ & $\infty$ \\
\hline $\begin{array}{l}\text { Calibration certificate for the } \\
\text { thermometer }(50 \mathrm{~mL}) *\end{array}$ & $1.34 \times 10^{-02}$ & normal & 2 & 0.004 & $2.52 \times 10^{-05}$ & $\infty$ \\
\hline $\begin{array}{l}\text { Volume expansion coefficient of } \\
\text { the alcohol }(50 \mathrm{~mL})\end{array}$ & $2.8 \times 10^{-03}$ & $\begin{array}{l}\text { rectang } \\
\text { ular }\end{array}$ & $\sqrt{3}$ & 0.004 & $6.47 \times 10^{-06}$ & $\infty$ \\
\hline $\begin{array}{l}\text { Calibration certificate for the } \\
\text { easuring cylinder }(99 \mathrm{~mL})\end{array}$ & 0.2 & normal & 2.25 & 0.02 & $1.78 \times 10^{-03}$ & $\infty$ \\
\hline $\begin{array}{l}\text { alibration certificate for the } \\
\text { thermometer }(99 \mathrm{~mL}) *\end{array}$ & $2.49 \times 10^{-03}$ & normal & 2 & 0.02 & $2.49 \times 10^{-05}$ & $\infty$ \\
\hline $\begin{array}{l}\text { Volume expansion coefficient of } \\
\text { the water }+ \text { alcohol }(99 \mathrm{~mL})\end{array}$ & $2.21 \times 10^{-03}$ & $\begin{array}{l}\text { rectang } \\
\text { ular }\end{array}$ & $\sqrt{3}$ & 0.02 & $2.55 \times 10^{-05}$ & $\infty$ \\
\hline Combined Uncertainty & & normal & & & $2.54 \times 10^{-03}$ & $\infty$ \\
\hline $\begin{array}{l}\text { Expanded Uncertainty } \\
(95 \%: k=2)\end{array}$ & & normal & & & $\begin{array}{c}5.1 \times 10^{-03} \\
(0.51 \%)\end{array}$ & $\infty$ \\
\hline
\end{tabular}

Table 2 - Level of Hydrocarbons Present in Anhydrous Ethyl Alcohol Fuel .

$$
\begin{aligned}
& C \%=\text { percent of hydrocarbons; } \\
& \begin{array}{c}
V_{\text {total }}=\text { total volume of liquid, alcohol + water; } \\
V_{\text {(fase aquosa) }}=\text { volume of the aqueous phase after } \\
\text { extraction; }
\end{array} \\
& V_{\text {i(álcool) }}=\text { initial alcohol volume. }
\end{aligned}
$$




\section{RELATIVE DENSITY IN PETROLEUM PRODUCTS - ASTM D 1298}

In tests to measure the density of a petroleum product and specific mass of ethyl alcohol and its mixtures, the same methodologies are used, so their respective uncertainty results tables follow the same format. The measurement equation is as in the following expression:

$\rho_{20^{\circ} C}=\rho_{20(1)}+\left\{\frac{\left[\left(\rho_{\text {medido }}-\rho_{1}\right) \cdot\left(\rho_{20(2)}-\rho_{20(1)}\right)\right]}{\rho_{2}-\rho_{1}}\right\}$, where $\rho_{20^{\circ} \mathrm{C}}=$ product density at $20^{\circ} \mathrm{C}$;

$\rho_{20(1)}=$ density corrected for $20^{\circ} \mathrm{C}(0.7893)$ lower limit conform Petroleum Measurement Table; $\left.26^{\circ} \mathrm{C}\right)$

$\rho_{\text {medida }}=$ density measured by the densimeter at $(0.7852$;

$\rho_{1}=$ observed density $(0.785)$ lower limit Petroleum Measurement Table;

$\rho_{2}=$ observed density $(0.786)$ upper limit Petroleum Measurement Table;

$\rho_{20(2)}=$ density corrected for $20^{\circ} \mathrm{C}(0.7903)$ upper limit Petroleum Measurement Table.

\begin{tabular}{|c|c|c|c|c|c|c|}
\hline $\begin{array}{l}\text { Sources } \\
\text { uncertainty }\end{array}$ & Value & Distribution & Divisor & $\begin{array}{l}\text { Sensitivity } \\
\text { coefficient }\end{array}$ & Uncertainty & $\begin{array}{l}\text { Degrees of } \\
\text { freedom }\end{array}$ \\
\hline $\begin{array}{l}\text { Lower limit of the } \\
\text { density corrected } \\
\text { for } 20^{\circ} \mathrm{C} \rho_{20(1)}\end{array}$ & 0.0001 & rectangular & $\sqrt{3}$ & 0.8 & 0.000046 & $\infty$ \\
\hline $\begin{array}{l}\text { Certificate of the } \\
\text { densimeter } \rho_{\text {medida }}\end{array}$ & 0.0003 & normal & 2 & 1 & 0.00015 & $\infty$ \\
\hline $\begin{array}{l}\text { Lower limit } \\
\text { observed for the } \\
\text { densimeter } \rho_{1}\end{array}$ & 0.0001 & rectangular & $\sqrt{3}$ & 0.8 & 0.000046 & $\infty$ \\
\hline $\begin{array}{l}\text { Upper limit of the } \\
\text { density corrected } \\
\text { for } 20^{\circ} \mathrm{C} \rho_{20(2)}\end{array}$ & 0.0001 & rectangular & $\sqrt{3}$ & 0.2 & 0.000012 & $\infty$ \\
\hline $\begin{array}{l}\text { Upper limit } \\
\text { observed for the } \\
\text { densimeter } \rho_{2}\end{array}$ & 0.0001 & rectangular & $\sqrt{3}$ & 0.2 & 0.000012 & $\infty$ \\
\hline $\begin{array}{l}\text { Calibration } \\
\text { certificate of the } \\
\text { thermometer }\end{array}$ & $0.12^{\circ} \mathrm{C}$ & Normal & 2 & $\begin{array}{c}0.0008 \\
{ }^{0} \mathrm{C}\end{array}$ & 0.000048 & $\infty$ \\
\hline $\begin{array}{l}\text { Combined } \\
\text { Uncertainty }\end{array}$ & & normal & & & 0.00015 & $\infty$ \\
\hline $\begin{array}{l}\text { Expanded } \\
\text { Uncertainty } \\
(95 \%: k=2)\end{array}$ & & normal & & & 0.00030 & $\infty$ \\
\hline
\end{tabular}

Table 3 - Relative Density of Petroleum Products.

\section{CONCLUSIONS}

\section{LEVEL OF ANHYDROUS ETHYL ALCOHOL} PRESENT IN AUTOMOTIVE GASOLINE NBR 13992 AND LEVEL OF HYDROCARBONS PRESENT IN ANHYDROUS ETHYL ALCOHOL FUEL NBR 13993

By analyzing the tables showing the estimates of uncertainties in the tests of alcohol and hydrocarbon content it can be concluded that the overwhelming factor of uncertainty in the measurement of these tests arose from the calibration certificate of the measuring cylinder.

It is therefore clear that the measuring cylinders need to be calibrated, since the measurements of alcohol and hydrocarbon content are the most significant and simple of the tests that can be conducted to verify the quality of the product, which is controlled through inspections made by government agencies.

It is further observed that the estimated uncertainties in the measurements in the tests for alcohol and hydrocarbon content are to the order of $0.51 \%$, which is compatible with the $1 \%$ tolerance limit, as specified in ANP Regulations \#197 of December 28, 1999 and \# 45 of March 16, 2001, respectively.

It is common for measuring cylinders to be damaged during routine testing. Given the importance of the uncertainty of the measurement made by the measuring cylinders in these tests, and the cost of calibrating them, laboratories should take the measure of establishing a working routine to prevent their being damaged. 
As regards the calibrations of the measuring cylinders, it is suggested that they be calibrated for $50,60,65,70$ and 100 $\mathrm{mL}$, since these are the nominal values routinely measured in these tests. This decision is opportune given the precise nature of uncertainty in measurements and the cost of calibrating these instruments.

In establishing the validation of this type of test with operators, their respective dispersions must be compatible with the uncertainty stated on the calibration certificate of the measuring cylinder. If this does not happen, the greater uncertainty in the test will be that of the operator, which entirely compromises the suitability of the uncertainty to the tolerance of the respective test.

In view of the instrumentation that is currently used, it is necessary that an evaluation of the tolerance limits established by current regulations for the instrument be made.

\section{RELATIVE DENSITY IN PETROLEUM PRODUCTS - ASTM D 1298}

On analyzing the results of the estimates of uncertainties of the relative density tests, it was concluded that the key factor of uncertainty in the measurement of these tests was the uncertainty derived from the calibration certificate of the densimeter.

The value for expanded uncertainty estimated for these tests is 0.0003 . This figure, compared with the 0.0005 , which is the repeatability of the tests according to Standard ASTM D 1298, shows the need for the densimeters to be calibrated.

As mentioned in the previous paragraphs, in any of the situations, laboratories should always make an effort to show their competence and the metrological reliability of their results, especially in these tests, where the values for the uncertainty of the measurement and the tolerance limit are very close. In any situation, the most highly recommended way of providing such evidence is to implant and implement the standard "NBR ISO/IEC 17025:Requisitos Gerais para Competência de Laboratórios de Ensaio e Calibração- JAN 2001".

The specific mass at $20^{\circ} \mathrm{C}$ is what is used in the sale of gasoline. If refueling is done with a truck whose tank has a $32 \mathrm{~m}^{3}$ capacity, with gasoline that has a specific mass of $(767.5 \pm 0.3) \mathrm{kg} / \mathrm{m}^{3}$, this uncertainty leads to the waste of around $12.8 \mathrm{~L}$ of the product per tankload. If we add up the national daily waste in 20 days in the refueling of 500 gas transport trucks with the same capacity, the waste is around $127.9 \mathrm{~m}^{3}$ gasoline. This is the equivalent of four trucks with a $32 \mathrm{~m}^{3}$ capacity per month. These figures suggest the need for efforts to be made to improve the uncertainty in the measurement of these tests.

Given the whole panorama shown in this work, the laboratory should establish consistent procedures to validate its test methods, as well as taking wider responsibility than that of simply conducting tests of products.

\section{ACKNOWLEDGEMENTS}

The authors wish to thank the professors from the EQ/ UFRJ that coordinate the LABCOM and the partners of INMETRO/LAMOC for their collaboration in reviewing this work and to Leandro J. Rodrigues Pereira and Estevam Pandini Neto for making the measurements in the laboratory.

\section{REFERENCES}

I. Vocabulário Internacional de Termos Fundamentais e Gerais de Metrologia - INMETRO (Segunda Edição 1993);

II. Tabelas de Correção das Densidades e dos Volumes dos Produtos de Petróleo -Petróleo Brasileiro S.A 1970 -Conselho Nacional do Petróleo - Instituto Nacional de Pesos e Medidas;

III. Couto,PRG, Monteiro,LC; A Função de um Laboratório de Metrology de acordo com o contexto de globalização, Metrology 2000São Paulo-Brazil- December 2000;

IV. Requisitos Gerais para Competência de Laboratórios de Ensaio e Calibração- NBR ISO/IEC 17025: JAN 2001;
V. International Organization for Standardization, Guide to the Expression of Uncertainty in Measurement,Geneva,1993, revised and reprinted in 1995" (ISO GUM 95);

VI. Teor de Álcool Etílico Anidro Combustível em Gasolina Automotiva - NBR 13992;

VII. Teor de Hidrocarbonetos em Álcool Etílico Anidro Combustível - NBR 13993;

VIII. Densidade Relativa em Produtos de Petróleo ASTM D 1298 